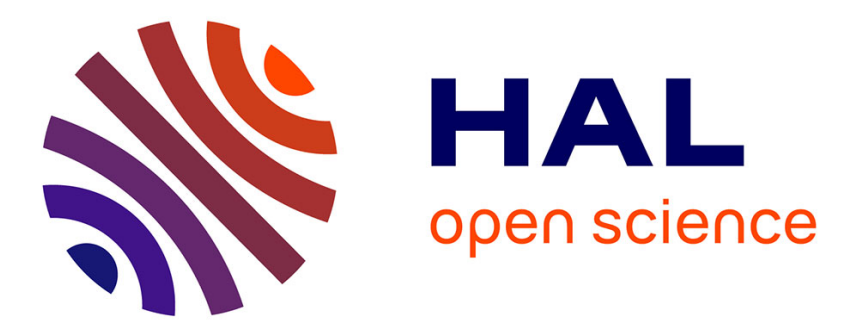

\title{
Angular correlation study of some highly excited levels of 160
}

\author{
M. Avril, M. Lepareux, N. Saunier, A. Foti, G. Pappalardo, A. Strazzeri
}

\section{To cite this version:}

M. Avril, M. Lepareux, N. Saunier, A. Foti, G. Pappalardo, et al.. Angular correlation study of some highly excited levels of 16O. Journal de Physique Lettres, 1975, 36 (10), pp.229-231. 10.1051/jphyslet:019750036010022900 . jpa-00231194

\section{HAL Id: jpa-00231194 https://hal.science/jpa-00231194}

Submitted on 1 Jan 1975

HAL is a multi-disciplinary open access archive for the deposit and dissemination of scientific research documents, whether they are published or not. The documents may come from teaching and research institutions in France or abroad, or from public or private research centers.
L'archive ouverte pluridisciplinaire HAL, est destinée au dépôt et à la diffusion de documents scientifiques de niveau recherche, publiés ou non, émanant des établissements d'enseignement et de recherche français ou étrangers, des laboratoires publics ou privés. 
Classification

Physics Abstracts

$4.375-4.420-4.260$

\title{
ANGULAR CORRELATION STUDY OF SOME HIGHLY EXCITED LEVELS OF ${ }^{16} \mathrm{O}$
}

\author{
M. AVRIL, M. LEPAREUX, N. SAUNIER
}

Département de Physique nucléaire CEN Saclay, BP 2, 91190, Gif-sur-Yvette, France

\section{A. FOTI, G. PAPPALARDO, A. STRAZZERI}

Centro Siciliano di Fisica Nucleare e Struttura della Materia $\left({ }^{*}\right)$ Istituto Nazionale di Fisica Nucleare, Catania, Italia

(Reçu le 28 avril 1975, révisé le 4 juillet 1975, accepté le 9 juillet 1975)

\begin{abstract}
Résumé. - Des expériences de corrélation angulaire ${ }^{12} \mathrm{C}\left({ }^{6} \mathrm{Li}, \mathrm{d}\right){ }^{16} \mathrm{O} \rightarrow \alpha_{0}+{ }^{12} \mathrm{C}_{\mathrm{g} . s .}$, faites à $0^{0}$, ont permis d'étudier plusieurs états de ${ }^{16} \mathrm{O}$, entre 20 et $24 \mathrm{MeV}$. Un contrôle de la méthode a été fait sur le niveau $6^{+}$à $16,3 \mathrm{MeV}$, bien identifié. D'une analyse détaillée autour du pic large à 20,9 il ressort qu'aucun niveau $8^{+}$ne peut être mis en évidence dans cette région. Le résultat est en accord av̀ec l'attribution de $7^{-}$faite précédemment. Un spin 6 est attribué au niveau à 21,8 $\mathrm{MeV}$, observé dans les réactions $\left({ }^{6} \mathrm{Li}, \mathrm{d}\right)\left({ }^{7} \mathrm{Li}, \mathrm{t}\right)$.
\end{abstract}

Abstract. - Angular correlation measurements at $0^{\circ}$ involving the reaction

$$
{ }^{12} \mathrm{C}\left({ }^{6} \mathrm{Li}, \mathrm{d}\right){ }^{16} \mathrm{O} \rightarrow \alpha_{0}+{ }^{12} \mathrm{C}_{\mathrm{g} . \mathrm{s} .}
$$

have been used to study several highly excited states in ${ }^{16} \mathrm{O}$, between 20 and $24 \mathrm{MeV}$. The method has been tested using the known $6^{+}$at $16.3 \mathrm{MeV}$. No indication of a $8^{+}$level was found from detailed analysis around the 20.9 broad peak ; our result is in agreement with earlier assignment of $7^{-}$for this level. A spin 6 is assigned to the 21.8 level, observed in $\left({ }^{6} \mathrm{Li}, \mathrm{d}\right)$ and $\left({ }^{7} \mathrm{Li}, \mathrm{t}\right)$ data.

The investigation of quartet and $\alpha$-like states in sd shell nuclei has been in the last few years the object of increasing attention due to the development of experimental techniques and of new ideas on nuclear models [1]; one of the most interesting features of the experimental data [2] is the evidence that selectively populated states also occur at high excitation energy (20-30 MeV and more) indicating the persistence at these energies of simple nuclear structure and simple symmetry properties. There is at this time little direct experimental information on the properties of these highly excited states (spin, parity, decay modes) and more data would be desirable.

In our laboratory $\mathrm{Li}$-induced $\alpha$ particle transfer reactions have been extensively used to investigate in detail this excitation region $[3,4]$. The present work is a preliminary report on the experimental study of some highly excited levels of ${ }^{16} \mathrm{O}$ populated by the

(*) According to the contract BT-II/12.766 between the CEN Saclay and the CSFN/SM, Catania.
${ }^{12} \mathrm{C}\left({ }^{6} \mathrm{Li}, \mathrm{d}\right){ }^{16} \mathrm{O}$ reaction. In the energy region around $20 \mathrm{MeV}$ of excitation broad and more or less marked structures are apparent in the deuteron energy spectrum (see Fig. 1); they are superimposed to a continuous background probably due to the break-up of ${ }^{6} \mathrm{Li}$ ions. The strong peak at $20.9 \mathrm{MeV}$ has been

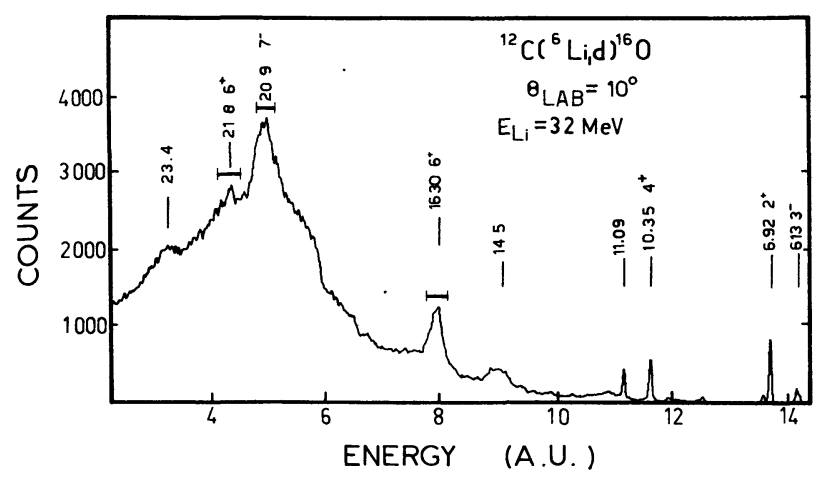

Fig. 1. - Deuteron spectrum from the ${ }^{12} \mathrm{C}\left({ }^{6} \mathrm{Li}, \mathrm{d}\right){ }^{16} \mathrm{O}$ reaction at $32 \mathrm{MeV}$. The lines $\longmapsto$ correspond to the energy interval covered by the PSD placed in the focal plane of the spectrometer. 
identified as the $7^{-}$state of a negative parity rotational band $[5,6]$; there is at present no indication of the expected [7] $\left(^{1}\right) 8^{+}$member of the first positive rotational band. One of the purposes of this work is to obtain new information on this energy region through a direct measurement of level properties by particle-particle correlation method.

It has been shown $[6,8]$ that, if the deuterons are detected at $0^{\circ}$ with respect to the beam (method II of Litherland and Ferguson), the angular correlation of $\alpha$ particles in the ${ }^{12} \mathrm{C}\left({ }^{6} \mathrm{Li}, \mathrm{d}\right){ }^{16} \mathrm{O} \rightarrow{ }^{12} \mathrm{C}_{\text {g.s. }}+\alpha$ is given by :

$$
W(\theta)=\Sigma_{m} B_{m}(m)\left[Y_{I}^{m}(\theta, 0)\right]^{2}
$$

where $I$ is the spin of the ${ }^{16} \mathrm{O}$ decaying level.

The geometry of the system implies that only magnetic substates with $m=0, \pm 1, \pm 2$ can be populated $[6,8,9]$. The $B(m)$ in eq. (1) cannot be calculated explicitly without knowledge of the mechanism of the reaction leading to ${ }^{16} \mathrm{O}$-states.

In a simple approximation, if the $\left({ }^{6} \mathrm{Li}, \mathrm{d}\right)$ reaction proceeds by direct transfer of an $\alpha$-particle and no spin-flip is assumed, the $B(m)$ for $m \neq 0$ should be suppressed [6,9] and eq. (1) reduces to the simple expression :

$$
W(\theta) \propto P_{I}(\cos \theta)^{2} .
$$

Where $P_{I}(\cos \theta)$ is the Legendre polynomial of degree $I$. In eq. (2) it is also assumed that the solid angle subtended by the $0^{\circ}$ detector is sufficiently small $[10,11]$. It is to be noted that, due to the selected geometry of our experimental arrangement, no angular shift is to be applied to fit the experimental data with the $P_{I}(\cos \theta)^{2}$ function [6].

In our experiment the deuterons were detected at $0^{\circ}$ by means of a magnetic spectrometer equipped with a $50 \times 14 \mathrm{~mm}$ position sensitive detector (PSD) $600 \mu \mathrm{m}$ thick placed in the focal plane; the surface was protected by a gold foil $50 \mu \mathrm{m}$ thick to prevent damage due to the direct lithium beam; the decay $\alpha$-particles were detected by a second $50 \times 14 \mathrm{~mm}$, $300 \mu \mathrm{m}$ thick PSD placed at $80 \mathrm{~mm}$ from the center of the scattering chamber with its sensitive surface defined by a grid with 13 slits $2 \mathrm{~mm}$ wide. The halfangle subtended by the magnetic spectrometer was $\pm 3.5 \times 10^{-2} \mathrm{rad}$. The ${ }^{6} \mathrm{Li}^{+++}$beam was produced by the FN Tandem VdG of Saclay laboratory; the deuteron energy resolution was about $100 \mathrm{keV}$. An overall time resolution of 40 ns was obtained using a time compensation method [12].

Energy and position signals from the two detectors and the time signal were pretreated on-line and simultaneously recorded on magnetic tape for off-line analysis [13].

Figure 2 shows the results for the two known ${ }^{16} \mathrm{O}$ levels at 16.3 and $20.9 \mathrm{MeV}$ respectively; our data

( $\left.{ }^{1}\right)$ Zuker, A. P., Mc Grory, J. B., private communication. confirm the previous assignment of $6^{+}$and $7^{-}$respectively [6]; both levels are found to strongly decay to the ${ }^{12} \mathrm{C}_{\text {g.s. }}$. No significant change in the correlation function was noted when the data of the $20.9 \mathrm{MeV}$ broad peaks were analyzed off-line with a deuteron energy window corresponding to $150 \mathrm{keV}$ and spanning the deuteron peak from 20.7 to $21.1 \mathrm{MeV}$.
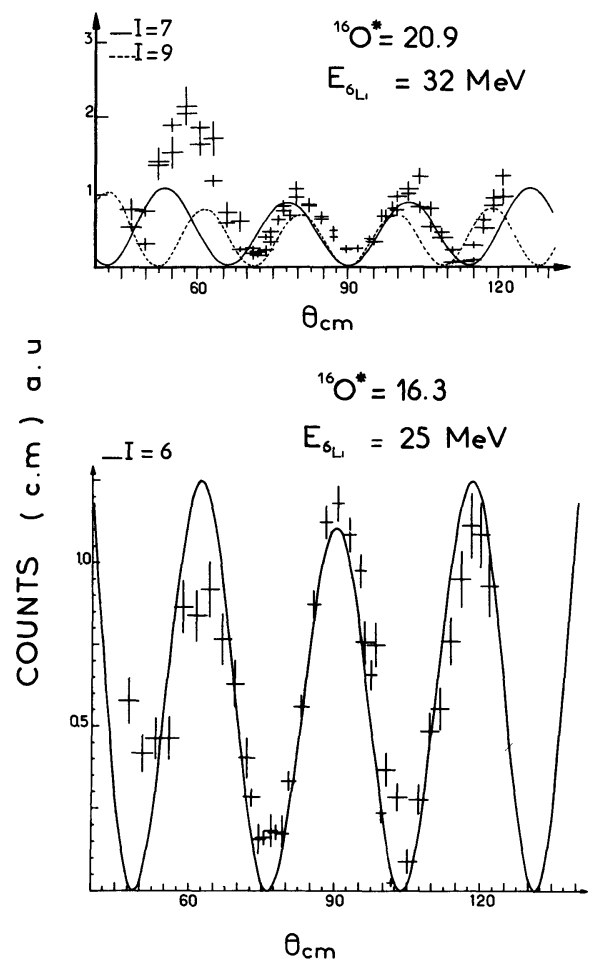

FIG. 2. - Results of the correlation measurement for the 16.3 and $20.9 \mathrm{MeV}$ levels respectively, the $6^{+}$and $7^{-}$previous values of the spin are confirmed.

Figure 3 shows the results concerning the ${ }^{16} \mathrm{O}$ level at $21.8 \mathrm{MeV}$; this peak is evident in the experimental $\left({ }^{7} \mathrm{Li}, t\right)$ data of M. E. Cobern [14]; but it is not reported in $(\alpha, \alpha)$ and $\left(\alpha, \alpha^{\prime}\right)$ experiments [5, 15]. In spite of the large errors and the presence of the background, a $6^{+}$spin and parity assignment for this level can be made; it decays predominantly to the first $2^{+}$excited level of ${ }^{12} \mathrm{C}$ at $4.43 \mathrm{MeV}$.

The amount of available information is at this time not sufficient to have a complete understanding on the structure of this level. However we point out that its excitation energy $(\sim 20 \mathrm{MeV})$ and its decay

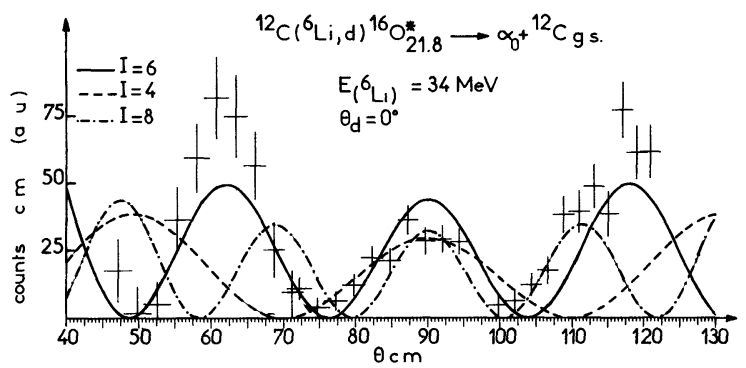

FIG. 3. - Results of the correlation measurements for the 21.8 level. The solid line is the $\left[P_{6}(\cos \theta)\right]^{2}$ function. 
mode suggest an interpretation in terms of the weakcoupling model [16], this level could arise from the coupling of the $2^{+}$state of ${ }^{12} \mathrm{C}$ and the $6^{+}$state of ${ }^{20} \mathrm{Ne}$. Further work on this line is in progress.

The authors are indebted to A. Da Silveira and A. Cunsolo for useful suggestions in the data ana- lysis, to J. P. Fouan and R. Moreau for writing the data acquisition program and to $\mathrm{L}$. Bianchi for helpful comments on the experimental design. Three of the authors want to express their gratitude to Professor E. Cotton for hospitality at the Centre d'Etudes Nucléaires de Saclay.

\section{References}

[1] Bethge, K., Annu. Rev. Nucl. Sci. 20 (1970) 255.

BASSANI, G., Note CEA-N-1474 (1971).

Arima, A., Gillet, V., Ginocchio, J., Phys. Rev. Lett. 25 (1970) 1043

[2] Gold'berg, V. Z., Bull. Acad. Sci. U.S.S.R., Phys. ser., 33 (1969) 525-550, 3 papers.

Zurmühle, R. W., Balamuth, D. P., Fifield, L. K., NoÉ, J. W., Phys. Lett. 44B (1973) 453.

[3] Bassani, G., Foti, A., Pappalardo, G., Saunier, N., Traoré, B. M., J. Physique Colloq. 32 (1971) C6-135.

Foti, A., Gerardin, C., Lepareux, M., Pappalardo, G., Saunier, N., Strazzeri, A., Wéry, M., Lett. Nuovo Cimento 8 (1973) 725.

[4] Bassani, G., Pappalardo, G., Saunier, N., Traoré, B. M., Phys. Lett. 34B (1971) 612.

[5] Carter, E. B., Mitchell, G. E., Davis, R. H., Phys. Rev. 133B (1964) 1421.

CARTer, E. B., Phys. Lett. 27B (1968) 202.

[6] Artemov, K. P., Gol'dberg, V. Z., Petrov, I. P., Rudakov, V. P., Serikov, I. N., Timofeev, V. A., Phys. Lett. 37B (1971) 61 .
Artemov, K. P., Gol'dberg, V. Z., Petrov, I. P., Rudakov, V. P., Serikov, I. N., Timofeev, V. A., Sov. J. Nucl. Phys. 14 (1972) 165.

[7] Kelson, I., Phys. Lett. 16 (1965) 143.

Celenza, L. S., Dreizler, R. M., Klein, A., Dreiss, G. J., Phys. Lett. 23 (1966) 241.

[8] Litherland, A. E., Ferguson, A. J., Can. J. Phys. 39 (1961) 788.

[9] Balamuth, D. P., Phys. Rev. C 3 (1971) 1565.

[10] Kuehner, J. A., Phys. Rev. 125 (1962) 1650.

[11] Panagiotou, A., Gove, H. E., Harar, S., Phys. Rev. C 5 (1972) 1995.

[12] Fouan, J. P., Passerieux, J. P., Note CEA-N-1232 (1969) 63.

[13] Lepareux, M., Note CEA-N-1791 (1975).

[14] Cobern, M. E., Thesis (1974) Yale University.

[15] Mitchell, G. E., Carter, E. B., Davis, R. H., Phys. Rev. $133 B$ (1964) 1434.

[16] Arima, A., Horiuchi, H. and Sebe, T., Phys. Lett. 24B (1967) 129 